\title{
Hunting and consumption of mammals and birds by people in urban areas of western Madagascar
}

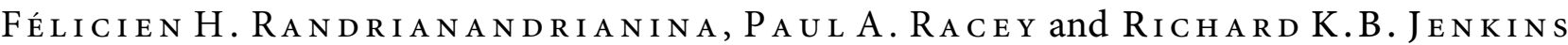

\begin{abstract}
We assessed the consumption and hunting of wild animals by people in urban areas of western Madagascar using structured questionnaires in households and direct observations. Six wild mammal and five wild bird species were reported, or observed, to be sources of bushmeat although fish and domestic animals were the preferred and cheapest sources of animal protein. Bushmeat accounted for $10 \%$ of the meat consumed the day before our questionnaires were completed. Common tenrec Tenrec ecaudatus and bush pig Potamochoerus larvatus were the preferred wild meat and the former was also the most expensive type of meat. Taboos and strong dislikes limited the consumption of domestic pigs, bush pigs, goats, lemurs and fruit bats. Game species were hunted according to their availability, which coincided with the legal hunting season for fruit bats but only partly so for the other game species. Illegal hunting of Verreauxi's sifaka Propithecus verreauxi is cause for concern and assessments of primate consumption may have been underestimated because of reluctance of interviewees to admit illegal activities.
\end{abstract}

Keywords Bushmeat, fruit bat, hunting, lemur, Madagascar, taboo

\section{Introduction}

A lthough the consumption of bushmeat in parts of the tropics has received considerable attention, there is scant information available on the hunting of wild animals by people for food in Madagascar. It is nevertheless important to understand the hunting pressures on Madagascar's wild animals from both conservation and socio-economic perspectives. Madagascar's wildlife legislation permits the unrestricted hunting of pest species, with hunting of all other species strictly prohibited or permitted only with special authorization or when limited to defined periods (Durbin, 2007). This provides the framework within which lemur

Félicien H. Randrianandrianina and RichaRd K.B. Jenkins* ${ }^{\dagger}$ (Corresponding author) Madagasikara Voakajy, B. P. 5181, Antananarivo, Madagascar. E-mail rkbjenkins@gmail.com

PaUl A. RaCEy Institute of Biological and Environmental Sciences, University of Aberdeen, Aberdeen, UK

${ }^{*}$ Also at: Institute of Biological and Environmental Sciences, University of Aberdeen, Aberdeen, UK

${ }^{\dagger}$ Current address: School of the Environment and Natural Resources, Bangor University, Bangor, LL57 2UW, UK

Received 21 January 2009. Revision requested 11 March 2009.

Accepted 26 June 2009. hunting is prohibited but other endemic mammal species, such as tenrecs and bats, can be legally harvested at certain times of the year. There is growing evidence, however, that hunting is a major conservation issue because (1) of widespread hunting of protected species, (2) hunters operate illegally inside national parks, and (3) the exploitation of certain game species may be unsustainable (Randriamanalina et al., 2000; Garcia \& Goodman, 2003; Goodman \& Raselimanana, 2003; O'Brien et al., 2003; Rakotondravony, 2006; Dunham et al., 2008; Jenkins \& Racey, 2008; Golden, 2009). It is also necessary to understand bushmeat use and hunting culture in Madagascar from a livelihoods perspective because the income generated from legal hunting, or the protein obtained from consuming legally hunted bushmeat, makes a potentially important contribution to the diet of people living with low food security (Robinson \& Bennett, 1999; de Merode et al., 2004; Goodman, 2006). This study therefore aimed to determine which species are used as bushmeat and their relative importance compared to meat from domestic animals in settlements along a main road in western Madagascar.

\section{Methods}

Fieldwork was carried out during two main periods, to coincide with the austral winter (June-July 2007) and summer (January-February 2008). An additional shorter visit was also made in April 2008. We visited eight settlements along the main road from Antsirabe to Morondava in the District of Mahabo. This area has a significant amount of native forest cover remaining (Harper et al., 2007). We used structured interviews, informal discussions and direct observations to obtain data on the use of bushmeat. All interviews and observations were undertaken by FHR, who is familiar with the local dialect, and who was always accompanied by a local guide. We interviewed the head, or a person appointed by the household, of 228 households. Interviews were carried out in every other house, with the interviewers walking a zigzag route in each settlement (East et al., 2005). When we encountered an unoccupied house we moved to the next nearest house and repeated this until an interviewee was found. Interviewees were asked about the food they had eaten during the previous day and how much it cost (or the market value if not purchased), the quantity in $\mathrm{kg}$ and mode of procurement (either: purchased, hunted, reared or received as a gift; East et al., 2005; Albrechsten et al., 2006). 
We showed each interviewee colour photographs depicting sources of locally available animal protein. The interviewees were asked to order the pictures according to their taste preference, with the tastiest first. We also gave the option of three categorical replies: fady (taboo, animals that cannot be eaten for cultural or traditional reasons), never tasted (animals that the respondent could not comment on) or strong aversion (animals that the respondent had eaten once or twice but disliked the taste of so much that they could not contemplate giving it a preference score). We use the term bushmeat to refer to any type of meat derived from a wild animal and the term animal protein in reference to all meat (i.e. domestic and bushmeat) and fish.

Informal discussions with bushmeat hunters and direct observations of hunting were used to obtain information about the species hunted, the frequency of hunting, trapping methods and income generation. Hunters were encountered in an opportunistic manner and our data are not indicative of real hunting pressure. We also interviewed people selling meat in four village markets, to obtain prices $($ MGA $1,420=$ USD 1$)$.

\section{Results}

Animal protein from six wild mammal, five wild bird, four domestic fowl, three domestic livestock and a variety of fish species was eaten by people in our study area. We observed, or were informed about, the hunting and consumption of one species that is strictly protected from hunting, one protected species that can be hunted with authorization, seven game species and one pest species (Table 1). Of these only Verreauxi's sifaka Propithecus verreauxi, Madagascar flying fox Pteropus rufus and Madagascar straw-coloured bat Eidolon dupreanum are categorized as threatened species on the IUCN Red List (IUCN, 2009), all as Vulnerable.

Animal protein had been consumed in $82 \%$ of households on the day prior to our survey, with fish (25\%) and zebu meat $(28 \%)$ the most commonly eaten (Table 2). Excluding fish, domestic animals accounted for $47.4 \%$ and wild animals for $10.2 \%$ of the animal protein consumed. Common tenrec Tenrec ecaudatus and bush pig Potamochoerus larvatus were the most commonly eaten bushmeat. Animal protein was usually purchased $(82.2 \%)$ but was also procured through hunting (2.1\%), fishing (0.5\%), farming (9.6\%) and received as a gift $(0.5 \%)$. Common tenrecs $(n=4$ people) and fruit bats ( $\mathrm{n}=1$ person) were the only animals reportedly hunted by the respondents and no bushmeat was received as a gift. Respondents spent most money on domestic ducks, common tenrecs and helmeted guinea fowl Numida meleagris the day preceding the questionnaires (Table 2). Common tenrec meat was the most expensive, whereas other game species such as fruit bats and wild ducks were the cheapest meats available (Table 2).

Domestic meats and fish were the six most preferred meats overall with bush pig, common tenrec and helmeted guinea fowl the most preferred bushmeat (Table 3). Lemurs and civets scored highest in the strong aversion category. Fady was the primary reason for not eating domestic pigs, bush pigs, lemurs, goats and fruit bats. Generally therefore, the sources of animal protein were either mainly liked (e.g. chicken, fish), mainly disliked (e.g. lemur, parrot) or subject to both strong likes and dislikes (e.g. bush pig, goat). Common tenrec was notable for its high cost and high preference (Tables $2 \& 3$ ). There was noticeable seasonal

TABLE 1 List of wild animals that were reported or observed to be hunted or consumed by people in households in the Menabe Region, Madagascar, with IUCN Red List status (IUCN, 2009), national status (Durbin, 2007) and any relevant hunting rules. Endemic status $\left({ }^{*}\right)$ are from Morris \& Hawkins (1998), Mittermeier et al. (2006) and Racey et al. (2009).

\begin{tabular}{|c|c|c|c|c|}
\hline & Vernacular names (Malagasy, English) & Red List status ${ }^{1}$ & National status ${ }^{2}$ & Hunting rules \\
\hline \multicolumn{5}{|l|}{ Mammals } \\
\hline Propithecus verreauxi* & Sifaka, Verreauxi's sifaka & VU & Protected I & Prohibited \\
\hline Pteropus rufus ${ }^{*}$ & Fanihy, Madagascar flying fox & VU & Game & Restricted (1 May-1 Sep.) \\
\hline Eidolon dupreanum ${ }^{*}$ & $\begin{array}{l}\text { Angavo, Madagascar straw-coloured } \\
\text { fruit bat }\end{array}$ & VU & Game & Restricted (1 May-1 Sep.) \\
\hline Tenrec ecaudatus ${ }^{*}$ & Trandraka, common tenrec & LC & Game & Restricted (1 Apr.-31 May) \\
\hline Viverricula indica & Jaboady, Indian civet & LC & Not listed & Unrestricted \\
\hline Potamochoerus larvatus & Lambo, bush pig & LC & Pest & Unrestricted \\
\hline Birds & & LC & & \\
\hline Coracopsis vasa & Boezy, greater vasa parrot & LC & Protected II & Restricted (1 May-30 Sep.) \\
\hline Dendrocygna viduata & Vivy, white-faced whistling duck & LC & Game & Restricted (15 May-30 Sep.) \\
\hline Anas erythrorhyncha & Sadakely, red-billed teal & $\mathrm{LC}$ & Game & Restricted (15 May-30 Sep.) \\
\hline Sarkidiornis melanotos & Angongo, comb duck & LC & Game & Restricted (15 May-30 Sep.) \\
\hline Numida meleagris & Akanga, helmeted guinea fowl & LC & Game & Restricted (15 May-30 Sep.) \\
\hline
\end{tabular}

${ }^{1} \mathrm{VU}$, Vulnerable; LC, Least Concern (i.e. not threatened)

${ }^{2}$ Protected I, Class I, Category I; Protected II, Class I, Category II; Game, restricted hunting; Pest, no protection 
TABLE 2 Results from questionnaires in 228 households about meat consumption the previous day. Data are the percentage of households that consumed each type of meat, its mean value (calculated from interview data on meat quantity consumed and prices obtained during observations in village or from converting the price per animal based on the estimated body mass for fowl, fruit bat and tenrec), and prices per kilogram.

\begin{tabular}{|c|c|c|c|}
\hline $\begin{array}{l}\text { Meat consumed the } \\
\text { previous day }\end{array}$ & $\begin{array}{l}\% \text { of } \\
\text { respondents }\end{array}$ & $\begin{array}{l}\text { Mean }( \pm \mathrm{SE}) \\
\text { value }\left(\mathrm{USD} \mathrm{kg}^{-1}\right) \text { of } \\
\text { animal protein } \\
\text { eaten the previous day }\end{array}$ & $\begin{array}{l}\text { Prices of animal } \\
\text { protein }\left(\mathrm{USD} \mathrm{kg} \mathrm{kg}^{-1}\right)\end{array}$ \\
\hline Domestic cattle (zebu) & 28.1 & $1.5 \pm 0.13$ & 2.1 \\
\hline Fish & 24.6 & $0.7 \pm 0.40$ & 1.4 \\
\hline No meat & 18.0 & & \\
\hline Domestic chicken & 10.1 & $2.5 \pm 0.15$ & 2.1 \\
\hline Domestic duck & 4.8 & $3.2 \pm 0.21$ & 2.8 \\
\hline Common tenrec & 4.0 & $4.1 \pm 0.80$ & 7.0 \\
\hline Domestic pig & 3.5 & $2.0 \pm 0.26$ & 2.8 \\
\hline Bush pig & 3.1 & $1.9 \pm 0.30$ & 2.1 \\
\hline Fruit bat & 1.3 & $1.3 \pm 0.18$ & $0.9-1.4$ \\
\hline Helmeted guinea fowl & 1.3 & $3.3 \pm 0.24$ & $2.8-3.5$ \\
\hline Domestic goat & 0.9 & $1.6 \pm 0.54$ & 2.1 \\
\hline Wild duck & 0.5 & 1.0 & 1.4 \\
\hline
\end{tabular}

variation in the household consumption of certain bushmeat, with fruit bat and bush pig usually eaten in the winter and tenrec and helmeted guinea fowl in the summer (Fig. 1).

TABLE 3 Percentage of respondents who reported their preference for meat from different types of domestic and wild animal. Responses were either categorical (strong aversion/fady/never tasted) or ordinal (scores) where the frequency (\%) with which the animals were listed in the first five favourite sources of protein are presented.

\begin{tabular}{|c|c|c|c|c|}
\hline & Fady & Never tasted & $\begin{array}{l}\text { Strong } \\
\text { aversion }\end{array}$ & $\begin{array}{l}\text { Top } 5 \\
\text { preferred }\end{array}$ \\
\hline Domestic pig & 35.2 & 0 & 1.5 & 71.0 \\
\hline Domestic cattle (zebu) & 0 & 0 & 0 & 69.4 \\
\hline Fish $^{1}$ & 0 & 0 & 0.5 & 68.9 \\
\hline Domestic duck & 0 & 0 & 0 & 67.7 \\
\hline Domestic chicken & 1.5 & 0 & 1 & 66.5 \\
\hline Domestic turkey & 0 & 7.8 & 0 & 54.8 \\
\hline Bush pig & 34.6 & 1 & 2.5 & 49.6 \\
\hline Domestic goose & 0 & 12.3 & 0 & 49.0 \\
\hline Domestic goat & 34.8 & 30.2 & 0 & 46.7 \\
\hline Common tenrec & 9.9 & 2.2 & 4.4 & 46.3 \\
\hline Guinea fowl & 3.6 & 3.7 & 0.5 & 39.8 \\
\hline Fruit bat ${ }^{2}$ & 25.0 & 7.2 & 5.6 & 35.0 \\
\hline $\begin{array}{l}\text { White-faced } \\
\text { whistling duck }\end{array}$ & 1.4 & 3.2 & 0.7 & 31.6 \\
\hline Red-billed teal & 2.0 & 16.9 & 2.0 & 20.0 \\
\hline Comb duck & 1.5 & 10.8 & 0.7 & 13.4 \\
\hline Indian civet & 17.8 & 16.8 & 13.9 & 5.8 \\
\hline Lemur $^{2}$ & 31.0 & 15.0 & 15.5 & 5.4 \\
\hline Parrot & 6.0 & 24.0 & 4.0 & 3.0 \\
\hline
\end{tabular}

${ }^{1}$ Included native and introduced species

${ }^{2}$ General terms based on a single photograph and included a variety of species
Information was obtained from a total of 17 hunters about the number of animals they caught. Fruit bats $(P$. rufus and E. dupreanum) were hunted at night with nets as the bats fed on kapok Ceiba pentandra nectar in July or a fruiting voandelaka tree (Molinaea sp.) in January. Captures were observed on seven occasions in different locations and a minimum of five $P$. rufus were netted each night at kapok and 14 E. dupreanum at Molinaea sp.. Hunters reported that catching fruit bats was a seasonal pastime that generated additional income and that it was rare to obtain $>20$ bats per night. Hunters also reported selling the bats the following day either to the general public $(38 \%)$ or to both restaurants and the general public (50\%), or retaining the bats for family consumption (12\%). The selling price was usually USD $0.71(n=7)$. A single bush pig fetched USD 29-36 and hunting reportedly occurs throughout the year. Direct observations were made of one lemur hunt in which slingshots and dogs were used to kill five of the six Verreauxi's sifaka in a group. The carcasses were reportedly worth USD 1.4-1.6. Three tenrec hunters reported selling the animals to the general public or restaurants for USD 2.1-2.9 each. Tenrec hunting reportedly occurred between October and April, using dogs, and resulted in returns of up to 40 animals per hunt. Two wild duck hunters sold the birds to the general public or restaurants for USD 1.1 each and one reported that he hunted deliberately outside the open season because of the need to obtain meat for his family. We also observed the capture and consumption of an Indian civet Viverricula indica.

During winter there were five people selling bush pig meat (USD $2.1 \mathrm{~kg}^{-1}$ ) and three selling dead flying foxes (USD 1.4 each) in a market. In the summer only smoked carcasses of common tenrec (10 and 49 animals at different 


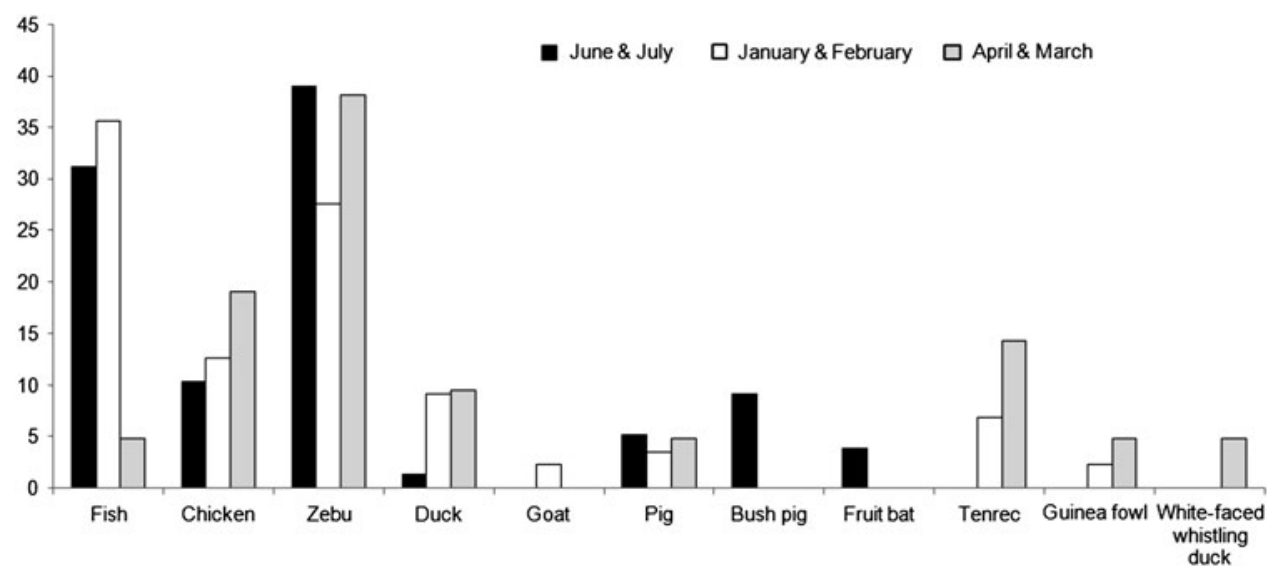

FIG. 1 Seasonal variation in the percentage of households that reported eating different types of animal protein in the 24-hour period prior to the interviews.

stalls) and helmeted guinea fowl (four and 40 at different stalls) were observed in the same market, retailing for USD 1.1-5.0 (depending on size) and USD 3.6 each, respectively. During March there were 16 smoked common tenrec carcasses for sale at one meat stall and our field assistant also encountered an attempt to sell two lemur carcasses surreptitiously for USD 1.8 each.

\section{Discussion}

The government of Madagascar is in the process of creating a suite of new protected areas, many of which will probably need to have sustainable use management policies, and it is clear that reducing illegal hunting and managing legal harvests of game species is a major challenge. The demand for bushmeat from urban centres around these new protected areas needs to be understood because people in towns and villages are major consumers of wild meat in other countries (Wilkie \& Godoy, 2001; East et al., 2005). Our study found evidence that six species of wild mammal species, including primates, carnivores and bats, as well as five wild bird species were consumed by people but that domestic animals were the most preferred sources of meat. Common tenrecs, helmeted guinea fowl, fruit bats and bush pig were consumed during our survey with factors such as seasonality and fady affecting the extent and frequency of consumption. Common tenrec was notable for being subject to fady by relatively few people, commanding a high retail price and a strictly seasonal (summer) consumption pattern. It was also the most preferred type of bushmeat on the grounds of taste. The high cost of the meat from this relatively common animal may be related to its tastiness and limited availability. Even though we obtained evidence of illegal lemur hunting, the combination of strong fady and low taste preference indicates that the demand for this type of meat is relatively low. However, we suspect that many people know it is illegal to kill, sell and eat lemurs, and we may therefore have underestimated the demand for this type of bushmeat because of the inevitable secrecy associated with consuming protected species.

The majority of species consumed as bushmeat are not strictly protected by wildlife legislation. The legal hunting seasons are not well known by hunters, or are ignored, and peaks in hunting activity for fruit bats and common tenrecs occurred when the animals were easiest to catch. However, even though the main trapping season for P. rufus coincided with the legal hunting season in Menabe the bats were always concealed when sold by market sellers. In contrast, common tenrecs were openly sold outside the legal hunting season. The impact of hunting on these species is poorly known, although there are reports of local depletion of common tenrecs in certain areas where hunting pressure is high (Ganzhorn et al., 1990; Favre, 1996; Nicoll, 2003) and numerous fruit bat species are threatened by hunting because of low reproductive rates and high offtake (Mickleburgh et al., 2009).

Conservation initiatives for the protected areas in Menabe Region should include raising awareness about the national wildlife legislation in local communities and among government personnel. This would be best accompanied by a justification for the prescribed hunting season for game species and a willingness to develop more flexible laws, which better reflect regional conditions, to support livelihoods and sustainable harvests. Barrett \& Ratsimbazafy (2009) recently drew attention to the upsurge in environmental crime in Madagascar and the increased urban demand for lemur meat, and greater effort is now needed to combat the illegal exploitation of protected species.

\section{Acknowledgements}

We would like to thank the Ministère de l'Environnement, des Forêts et du Tourisme for authorizing our study, which was undertaken as part of a bat conservation project in 
collaboration with the University of Aberdeen, Departément de Biologie Animale, Université d'Antananarivo and the Association Nationale pour la Gestion des Aires Protégées. We are grateful to the Peoples' Trust for Endangered Species and Cleveland Metroparks Zoo and The Cleveland Zoological Society for providing us with the financial resources to carry out the fieldwork. We are indebted to the many people who participated in the study, and thank Sambesoa, Mara Gaston and Razaka Jean Paule for help in the field, and Marcus Rowcliffe and Julia Jones for helpful comments.

\section{References}

Albrechiten, L., Fa, J.E., Barry, B. \& MacDonald, D.W. (2006) Contrasts in availability and consumption of animal protein in Bioko Island, West Africa: the role of bushmeat. Environmental Conservation, 32, 340-348.

Barrett, M.A. \& RatsimbaZAFy, J. (2009) Luxury bushmeat trade threatens lemur conservation. Nature, 421, 470.

de Merode, E., Homewood, K. \& Cowlishaw, G. (2004) The value of bushmeat and other wild foods to rural households living in extreme poverty in the Democratic Republic of Congo. Biological Conservation, 118, 573-581.

Dunham, A.E., Erhart, E.M., Overdorff, D.J. \& Wright, P.C. (2008) Evaluating effects of deforestation, hunting and El Nino events on a threatened lemur. Biological Conservation, 141, 287-297.

Durbin, J. (2007) New legislation for the protection of Malagasy species. Lemur News, 11, 4-6.

East, T., Kumpel, N.F., Milner-Gulland, E.J. \& Rowcliffe, J.M. (2005) Determinants of urban bushmeat consumption in Rio Muni, Equatorial Guinea. Biological Conservation, 126, 206-215.

Favre, J.-C. (1996) Traditional utilization of the forest. Primate Report, 46, 33-47.

Ganzhorn, J.U., Ganzhorn, A.W., Abraham, J.-P., Anriamanarivo, L. \& Ramananjatovo, A. (1990) The impact of selective logging on forest structure and tenrec populations in western Madagascar. Oecologia, 84, 126-133.

GarCia, G. \& Goodman, S.M. (2003) Hunting of protected animals in the Parc National d'Ankarafantsika, north-western Madagascar. Oryx, 37, 115-118.

Golden, C.D. (2009) Bushmeat hunting and use in the Makira forest, north-eastern Madagascar: a conservation and livelihoods issue. Oryx, 43, 386-392.

Goodman, S.M. (2006) Hunting of Microchiroptera in southwestern Madagascar. Oryx, 40, 225-228.

Goodman, S.M. \& Raselimanana, A.P. (2003) Hunting of wild animals by Sakalava of the Menabe region: a field report from Kirindy-Mite. Lemur News, 8, 4-5.
Harper, G.J., Steininger, M.K., Compton, J.T., Juhn, D. \& HAWkins, A.F.A. (2007) Fifty years of deforestation and forest fragmentation in Madagascar. Environmental Conservation, $34,1-9$.

IUCN (2009) 2009 IUCN Red List of Threatened Species, v. 2009.2. Http://www.iucnredlist.org [accessed 8 March 2010].

Jenkins, R.K.B. \& Racey, P.A. (2008) Bats as bushmeat in Madagascar. Madagascar Conservation and Development, 3 , $22-29$.

Mickleburgh, S., Waylen, K. \& Racey, P.A. (2009) Bats as bushmeat: a global review. Oryx, 43, 217-234.

Mittermeier, R.A., Konstant, W.R., Hawkins, A.F.A., Louis, E.E., Langrand, L., Ratsimbazafy, J. et al. (2006) Lemurs of Madagascar, 2nd edition. Conservation International, Arlington, USA.

Morris, P. \& Hawkins, A.F.A. (1998) Birds of Madagascar. A Photographic Guide. Pica Press, London, UK.

Nicoll, M.E. (2003) Tenrec ecaudatus, Tenrec, Tanraka, Trandraka. In The Natural History of Madagascar (eds S.M. Goodman \& J.P. Benstead), pp. 1283-1287. The University of Chicago Press, Chicago, USA and London, UK.

O'Brien, S., Emahalala, E.R., Beard, V., Rakotondrainy, R.M., Reid, A., Raharisoa, V. \& Coulson, T. (2003) Decline of the Madagascar radiated tortoise Geochelone radiata due to overexploitation. Oryx, 37, 338-343.

Racey, P.A., Goodman, S.M. \& Jenkins, R.K.B. (2009) The ecology and conservation of Malagasy bats. In Island Bats: Evolution, Ecology, and Conservation (eds T.H. Fleming \& P.A. Racey), pp. 369-404. The University of Chicago Press, Chicago, USA, and London, UK.

Rakotondravony, H. (2006) Communautés locales et gibiers dans la région de Daraina, extrême Nord-Est de Madagascar. Madagascar Conservation and Development, 1, 19-21.

Randriamanalina, M.H., Rafararano, L.B. \& Laha, R. (2000) Rapport des enquetes su les chasses dans les Fokontany d'Ivondro, d'Erara et d'Etsilesy. Lemur News, 5, 11-14.

Robinson, J.E. \& BENNETT, E.L. (eds) (1999) Hunting for Sustainability in Tropical Forests. Columbia University Press, New York, USA.

WILKIE, D.S. \& GODOY, R.A. (2001) Income and price elasticities of bushmeat demand in lowland Amerindian societies. Conservation Biology, 15, 761-769.

\section{Biographical sketches}

FÉLICIEN H. RANDRIANANDRIANINA specializes in bat conservation in western Madagascar. PAUL RACEY has been researching and conserving mammals in Madagascar for over 20 years. RICHARD JENKINS has broad interests in the conservation and ecology of threatened vertebrates in Madagascar. 